\title{
QUANTITATIVE ANALYSIS OF THE INFLUENCE OF TEMPERATURE AND CONFINING PRESSURE ON BRITTLENESS OF GRANITE: A REVIEW
}

\author{
Fei ZHAO ${ }^{1)}$, Qiang SUN ${ }^{2,3)}$ * and Weiqiang ZHANG ${ }^{1)}$ \\ ${ }^{1)}$ School of Resources and Geosciences, China University of Mining and Technology, Xuzhou, Jiangsu Province 221116, P.R. China \\ ${ }^{2)}$ Geological Research Institute for Coal Green Mining, Xi' an University of Science and Technology, \\ Xi'an, Shaanxi Province 710054, P.R. China \\ ${ }^{3)}$ College of Geology and Environment, Xi'an University of Science and Technology, \\ Xi'an, Shaanxi Province 710054, P.R. China \\ *Corresponding author 's e-mail: sunqiang04@cumt.edu.cn
}

\section{ARTICLE INFO}

Article history:

Received 14 August 2019

Accepted 14 January 2020

Available online 24 February 2020

Keywords:

Granite

Temperature

Confining pressure

Brittleness

\begin{abstract}
In order to quantitatively study the influence of temperature and confining pressure on brittle plasticity of granite, this paper reviews previous studies regarding quantitative calculation methods for the brittle-plastic behaviors of rocks and their mechanical characteristics under high temperatures and confining pressures. Combining the experimental results for temperatures and confining pressures with theoretical calculations of brittleness and plasticity allowed quantitative calculations and evaluations for the brittleness and plasticity of granite to be obtained. The main conclusions are as follows. (1) High temperatures lead to a transformation of granite from brittle failure to plastic failure. Comparing six conventional empirical equations from the literature, the $\mathrm{B}_{3}$ and $\mathrm{B}_{6}$ can more accurately describe the relationship between the brittleness and temperature of granite. (2) When the confining pressure $\sigma_{3}$ is less than $20 \mathrm{MPa}$, the internal pore structure and fractures of granite are re-compacted and reduced, which gradually increases its brittleness. With the increasing confining pressure, the pore structure changes again after exceeding $20 \mathrm{MPa}$. This initiates new cracks, which ultimately leads to a decrease of the granite brittleness. (3) The abrupt temperature for the brittle-plastic transformation of granite is approximately $800{ }^{\circ} \mathrm{C}$, and the brittle-plastic transformation of granite is mainly affected by temperature and not the confining pressure.
\end{abstract}

\section{INTRODUCTION}

The brittleness and plasticity of rocks are an important basis to evaluate their mechanical properties. To date, many researchers have studied the brittle plasticity of different rocks through experiments and proposed several quantitative methods to calculate their brittle plasticity (Walsh and Brace, 1964; Byerlee, 1968; Hucka and Das, 1974; Andreev, 1995; Altindag, 2002; Wong and Baud, 2012; Evans et al., 1990; Tarasov and Potvin, 2013; Paterson, 2013; Tarasov and Potvin, 2013; Luan et al., 2014; Meng et al., 2015; Stacey, 2016; Ai et al., 2016; Zhang et al., 2016; Chen et al., 2019). Based on the stress-strain curves, tensile strength and compressive strength, Hucka and Das (1974), Andreev (1995), and Altindag (2002) introduced some quantitative methods to calculate the brittleness and plasticity of rocks. Andreev (1995) suggested that the absolute irreversible longitudinal strain $\varepsilon_{\mathrm{li}}$ can be used to identify rock brittleness, because the $\varepsilon_{\text {li }}$ of brittle rocks is less than $3 \%$, the $\varepsilon_{\mathrm{li}}$ of plastic rocks is more than $5 \%$, and the brittleness of rocks in the brittle-plastic transition stage is between $3 \%$ and $5 \%$. Altindag (2002), Kahraman and Altindag (2004), and Gunaydin et al. (2004) suggested that for rock drillability, the fracture toughness and sawability of carbonate rocks using the area calculated under the $\sigma_{\mathrm{c}}-\sigma_{\mathrm{t}}$ curve to quantify the brittleness of rock masses can more accurately predict the rock properties related to brittleness. Jarvie et al. (2007), Wang and Gale (2009), and Jin et al. (2014a and 2014b) proposed quantitative calculations of rock brittleness by testing the type, weight, and content of the mineral components.

Differences in the brittle plasticity of rocks is not only reflected in the different mineral types but is also seen for the same rocks under the influence of high temperatures and pressures. In recent years, rock engineering under high temperatures or both high temperatures and confining pressures is an emerging subject of rock mechanics. There are many human or natural causes of high temperatures, such as the deep burial disposal of high radioactive nuclear waste (Hudson et al., 2001; Rutqvist et al., 2005; Emirov et al., 2013; Wang et al., 2015), the development of geothermal resources (Pearson et al., 1983; Ghassemi et al., 2007; Duan and Wang, 2012; Wang et al., 2018), tunnel fires (Gong and Zhao, 2007; Smith and Pells, 2008; Ozguven and Ozcelik, 2013; Tang et al., 2016), and coal spontaneous combustion (Ünal, 1995; Whitehouse and Mulyana, 2004; Voigt et al., 2004; Nolter and Vice, 2004), which further affect the physical and mechanical properties of rocks. For this reason, many researchers have simulated pressures and ground temperatures at certain depths below the earth surface using experimental methods with 
laboratory conditions, such as high-temperature pretreatment and uniaxial and triaxial compression tests. There has also been significant work on rock mechanical characteristics, failure modes, and brittle plasticity (Wan et al., 2007; Gong and Zhao, 2007; Xi et al., 2010; Yang et al., 2012; Xu et al., 2014; Sun et al., 2015; Zhang et al., 2016; Yang et al., 2017; Zhou et al., 2018).

Many of the above studies only describe the effects of the temperature and confining pressure on the physical and mechanical characteristics of rocks, while there are relatively few quantitative calculation methods used to study the degree of brittleness and plasticity of rocks. Therefore, this paper summarizes and compares several previous quantitative methods to calculate rock brittleness characteristics and combines these methods with previous experimental data. The brittleness index value is used to evaluate the brittleness and plasticity of granite under different temperatures and confining pressures, which provides a theoretical basis for future research of their influence on the mechanical properties of granite (Yarali and Kahraman, 2011).

In addition, this quantitative study on the relationship between both the temperature and confining pressure with brittle-plastic properties is of great significance when considering deep minerals and solving various geological and geophysical problems. With the increasing demand for minerals and geothermal resources in recent years, shallow resources have been unable to meet the needs of science, technology, and social development. Exploring and exploiting deep minerals and geothermal resources requires more in-depth studies on the deep structure of the earth. As one of the most effective exploration methods to understand the deep structure of the earth, drilling inevitably involves problems associated with high rock temperatures and confining pressures (Liu and $\mathrm{Xu}, 2014$ ). At the same time, the corresponding increases in temperature and pressure cause the rocks to transition from local brittle fractures to non-local plastic flow failure modes at a certain range of underground depths. This transformation is conducive to understanding various geological and geophysical problems, such as the focal mechanism and rheological model of the lithosphere (Girggs and Handin, 1960; Heard, 1960; Kaxiras and Duesbery, 1993; Amitrano, 2003; Niemeijer and Spiers, 2005; Sun et al., 2013).

\section{EXPERIMENTAL RESULTS OF PREVIOUS STUDIES}

This paper summarizes previous studies from two aspects. First, the theoretical methods to quantitatively calculate rock brittle-plasticity are reviewed. These methods mainly utilize the stressstrain curve, tensile strength, and compressive strength (Table 1). Each method has its preconditions and scope of application. Second, this paper summarizes a large amount of research data (Table 2) regarding rock mechanical characteristics under high temperatures and confining pressures. In previous experimental and theoretical studies, the effects of the temperature and confining pressure on the mechanical properties of granite were studied using mechanical tests on high-temperature treated granite, which included uniaxial and triaxial compressive strength tests. In this paper, the effects of the temperature and confining pressure on the brittle plasticity of granite are quantitatively studied. Combining the experimental results for the effects of temperature and pressure with the theoretical calculations of the brittle plasticity, a quantitative calculation and evaluation method for the brittle plasticity of granite under the effects of temperature and confining pressure is proposed.

\section{THE BRITTLENESS CALCULATION METHODS AND EXPERIMENTAL RESULTS \\ 3.1. CALCULATION METHODS OF ROCK BRITTLENESS}

Since the 1950s, there has been significant research on the brittle plasticity of rocks and several theoretical methods to quantitatively calculate the brittle plasticity have been proposed. This paper summarizes six theoretical methods to quantitatively calculate and evaluate the brittle plasticity of rocks based on the stress-strain curves, tensile strength, and compressive strength of rocks.

Hucka and Das (1974) analyzed the stress-strain curves for different brittle-plastic rocks and found that brittle rocks are destroyed when they produce relatively small strains. In contrast, plastic rocks undergo large inelastic strains without losing their bearing capacity before failure. From the analysis and comparison of the deformation and failure characteristics for these two types of rocks, two quantitative equations to calculate the brittle plasticity were proposed as given by Eqs. (1) and (2). Equation (1) gives the ratio of the elastic strain to the total strain (equal to the ratio of the EF and OF strains in Fig. 1), while Eq. (2) is the ratio of the elastic energy to the total failure energy (equal to the ratio of the areas for $\mathrm{CEF}$ and $\mathrm{OABCF}$ in Fig. 1). The two methods can be used to quantify the brittleness of any rock mass because the brittleness behavior of rocks indicates the energy absorbed from its deformation under stress. Greater ratios correspond to a larger brittleness.

$B_{1}=\frac{\varepsilon_{e l}}{\varepsilon_{t o t}}$

where $\varepsilon_{\mathrm{el}}$ is the elastic (recoverable) strain and $\varepsilon_{\mathrm{tot}}$ is the total strain at failure.

$B_{2}=\frac{W_{e l}}{W_{t o t}}$

where $W_{\text {el }}$ is the elastic energy at failure and $W_{\text {tot }}$ is the total energy at failure.

Andreev (1995) believed that when rocks are subjected to axial loads, inelastic or plastic deformations are characterized by irreversible longitudinal strains. Therefore, absolutely irreversible longitudinal strains can be used to quantify brittleness. For example, higher values of Eq. (3) (equals the OE 
Table 1 Several methods to calculate rock brittleness.

\begin{tabular}{|c|c|c|c|}
\hline Calculation basis & Brittleness & Calculation explanations & References \\
\hline \multirow{3}{*}{ Stress-strain test } & $B_{1}=\frac{\varepsilon_{\mathrm{el}}}{\varepsilon_{\mathrm{tot}}}$ & $\varepsilon_{\mathrm{el}}$ is the elastic (recoverable) strain and $\varepsilon_{\text {tot }}$ is the total strain at failure & (Hucka and Das, 1974) \\
\hline & $B_{2}=\frac{W_{\mathrm{el}}}{W_{\mathrm{tot}}}$ & $W_{\text {el }}$ is the elastic energy at failure, and $W_{\text {tot }}$ is the total energy at failure & (Hucka and Das, 1974) \\
\hline & $B_{3}=\varepsilon_{\mathrm{li}} * \underset{\sigma_{c}}{100 \%}$ & $\varepsilon_{\text {li }}$ is absolute irreversible longitudinal strain at failure & (Andreev, 1995) \\
\hline \multirow{3}{*}{ UCS test and BTS test } & $B_{4}=\frac{\sigma_{\mathrm{c}}}{\sigma_{\mathrm{t}}}$ & $\sigma_{\mathrm{c}}$ is the unconfined compressive strength and $\sigma_{\mathrm{t}}$ is the Brazilian tensile strength & (Hucka and Das, 1974) \\
\hline & $B_{5}=\frac{\sigma_{\mathrm{c}}-\sigma_{\mathrm{t}}}{\sigma_{\mathrm{c}+} \sigma_{\mathrm{t}}}$ & $\sigma_{\mathrm{c}}$ is the unconfined compressive strength and $\sigma_{\mathrm{t}}$ is the Brazilian tensile strength & (Hucka and Das, 1974) \\
\hline & $B_{6}=\frac{\sigma_{\mathrm{c}} * \sigma_{\mathrm{t}}}{2}$ & $\sigma_{\mathrm{c}}$ is the unconfined compressive strength and $\sigma_{\mathrm{t}}$ is the Brazilian tensile strength & (Altindag, 2002) \\
\hline
\end{tabular}

Table 2 Rock mechanical parameters under high temperatures and pressures.

\begin{tabular}{|c|c|c|c|c|c|}
\hline $\begin{array}{l}\text { Rock sample size } \\
(\mathrm{mm})\end{array}$ & $\begin{array}{c}\text { Temperature } \\
T\left({ }^{\circ} \mathrm{C}\right)\end{array}$ & Heating rate $\left({ }^{\circ} \mathrm{C} / \mathrm{min}\right)$ & $\begin{array}{c}\text { Holding time } \\
t(\mathrm{~h})\end{array}$ & $\begin{array}{c}\text { Confining pressure } \\
\sigma_{3}(\mathrm{MPa})\end{array}$ & References \\
\hline $50 \times 100$ & $25-1000$ & 5 & 4 & $0-15$ & (Hu et al., 2016) \\
\hline $50 \times 100$ & $25-1000$ & - & 2 & $0-40$ & (Xu et al., 2014) \\
\hline $\begin{array}{c}50 \times 25,50 \times 100,30 \times 100 \\
50 \times 100\end{array}$ & $25-1000$ & 10 & $2-3$ & 0 & (Liu and $\mathrm{Xu}, 2014$ ) \\
\hline $50 \times 100$ & $200-800$ & 5 & 2 & 0 & (Yang et al., 2017) \\
\hline $40 \times 80$ & $25-800$ & 10 & 6 & 0 & (Chen et al., 2012) \\
\hline $50 \times 25,50 \times 100$ & $25-900$ & 5 & 1 & 0 & (Zhang, 2017) \\
\hline $50 \times 25,50 \times 100$ & $25-600$ & 10 & 12 & 0 & (Gautam et al., 2015) \\
\hline $50 \times 25,50 \times 100$ & $25-600$ & 2 & 2 & 0 & (Jin et al., 2019) \\
\hline
\end{tabular}




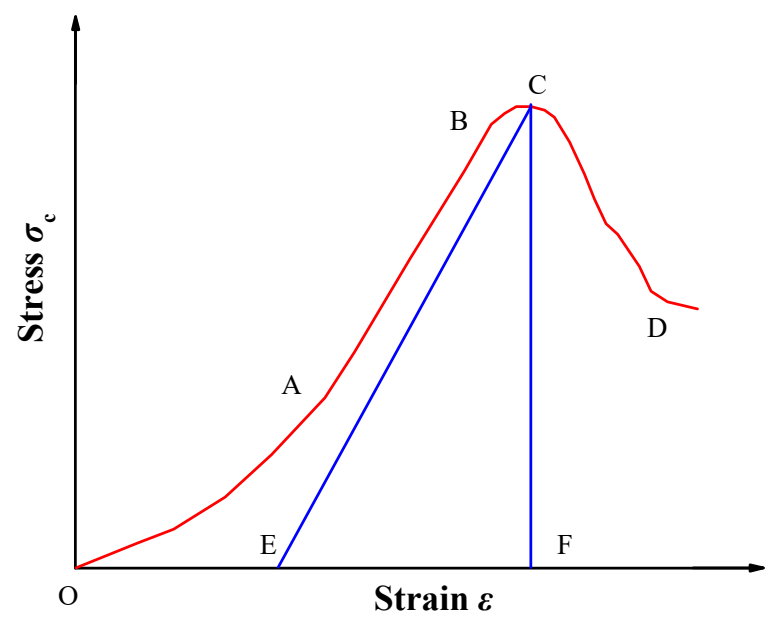

Fig. 1 Typical stress-strain curve for brittle rocks.

value in Fig. 1) correspond to a smaller brittleness.

$B_{2}=\varepsilon_{l i} * 100 \%$

where $\varepsilon_{\mathrm{li}}$ is the absolute irreversible longitudinal strain.

Hucka and Das (1974) found that the unconfined compressive strength (UCS) and Brazilian tensile strength (BTS) differ greatly when expressing the mechanical properties of brittle rocks. While the UCS shows the compressibility of a rock mass, the BTS shows the cohesion between rock mineral particles. Therefore, two equations are proposed as Eqs. (4) and (5).

$$
\begin{aligned}
& B_{4}=\frac{\sigma_{c}}{\sigma_{t}} \\
& B_{5}=\frac{\sigma_{c}-\sigma_{t}}{\sigma_{c}+\sigma_{t}}
\end{aligned}
$$

where $\sigma_{\mathrm{c}}$ is the compressive strength (UCS (MPa)) and $\sigma_{\mathrm{t}}$ is the tensile strength (BTS (MPa)).

Altindag (2002) then proposed and proved that the brittleness of a rock mass can be better quantified by using a function for the area under the $\sigma_{\mathrm{c}}-\sigma_{\mathrm{t}}$ curve after considering the drillability and fracture toughness of rocks. For example, higher values of Eq. (6) corresponds to a larger brittleness.

$$
B_{6}=\frac{\sigma_{c}+\sigma_{t}}{2}
$$

\subsection{THE INFLUENCE OF TEMPERATURE ON ROCK BRITTLENESS}

The relationships between the granite brittleness and temperature (Fig. 2) are obtained using Eqs. (1)(6). The brittleness from $B_{1}, B_{2}$, and $B_{6}$ decreases with the increase of temperature, and the brittleness from $B_{3}, B_{4}$, and $B_{5}$ increases with temperature overall. As shown in Figure 2(a), the value of $B_{1}$ decreases from $0.6-0.8$ to $0.3-0.6$ in the range of $25-1000{ }^{\circ} \mathrm{C}$. The value of $B_{2}$ decreases from $0.65-0.85$ to $0.5-0.65$ in the range of $25-1000{ }^{\circ} \mathrm{C}$, as shown in Figure 2(b). The value of $B_{3}$ increases from $0.05-0.25$ to 0.75 in the range of $25-1000{ }^{\circ} \mathrm{C}$ in Figure 2(c). Figure 2(d) shows that the value of $B_{4}$ increases from 10.17 and 15.90 to 16.32 and 52.62 in the range of $25-800{ }^{\circ} \mathrm{C}$. As shown in Figure. 2(e), the value of $B_{5}$ increases from 0.82 and 0.88 to 0.89 and 0.96 in the range of $25-800{ }^{\circ} \mathrm{C}$.
Figure 2(f) shows the value of $B_{6}$ decreases from 402.01 and 733.19 to 88.78 and 144.72 in the range of $25-800{ }^{\circ} \mathrm{C}$.

\subsection{THE INFLUENCE OF CONFINING PRESSURE ON ROCK BRITTLENESS}

The relationship between granite brittleness and the confining pressure is obtained by calculating and processing data from the literature using Eqs. (1), (2) and (3). Figure 3 shows the relationship between the brittleness and confining pressure as expressed using $B_{1}, B_{2}$, and $B_{3}$. At the range of $0-5 \mathrm{MPa}, B_{1}$ and $B_{2}$ increase overall in the range of $0-5 \mathrm{MPa}$, while $B_{3}$ decreases. Figure 3 also shows the relationship between the confining pressure and brittle-plastic behavior of rocks in the range of $0-40 \mathrm{MPa}$. The change trend for the brittleness can be divided into two stages. In Stage I (0-20 MPa), the brittleness as expressed by $B_{1}$ and $B_{2}$ increases, while the brittleness as expressed with $B_{3}$ has only slight changes. In Stage II (20-40 MPa), the brittleness as expressed with $B_{1}$ and $B_{2}$ decreases, while the brittleness expressed with $B_{3}$ increases.

\section{ANALYSIS AND DISCUSSION}

The brittle plasticity of rocks is affected by many factors in natural environments, such as the mineral composition, particle size, temperature, confining pressure, strain rate, liquid medium, etc., which lead to changes in the brittle-plasticity (Simpson, 1985; Horii and Nematnasser, 1986; Ellis and Stöckhert, 2004; Wong and Baud, 2012; Paterson, 2013; Duda and Renner, 2013; $\mathrm{Xu}$ et al., 2015). In this paper, the effect of temperature and confining pressure on the brittleness and plasticity of granite is summarized and studied, and the mechanism for the effects of temperature and confining pressure on the granite brittleness are analyzed.

The relationship between the brittleness and temperature are linearly fit in Figure 4 . The changes in $B_{1}, B_{2}, B_{3}, B_{4}, B_{5}$, and $B_{6}$ all indicate that the brittleness of granite decreases with increases in temperature. Compared with the other four methods, $B_{3}$ and $B_{6}$ can better express the relationship between temperature and brittleness. High temperatures cause thermal damage to the internal structure of granite. As the temperature increases, the adherent water and crystalline water in the granite overflow, which results in changes to the granite pore structure (Yoshitaka et al., 2010; Sun et al., 2013; Xu et al., 2014; Liu and $\mathrm{Xu}, 2015)$. In addition, because granite is composed of minerals with different thermal expansions, as the temperature continues to rise, the minerals produce non-uniform expansion deformations, which generates new cracks, i.e. intragranular and intergranular cracks (Somerton and Boozer, 1961; Xu et al., 2010; Sun et al., 2015; Zhang et al., 2016; Liu and Xu, 2014; Freire et al., 2016). Therefore, these changes in the internal structure of granite ultimately lead to a gradual reduction in its strength. As a result, the failure mode of granite gradually changes from brittle failure to plastic failure with the increasing temperature.

The variations of $B_{1}, B_{2}$, and $B_{3}$ in Figure 5 shows that different confining pressures have different 


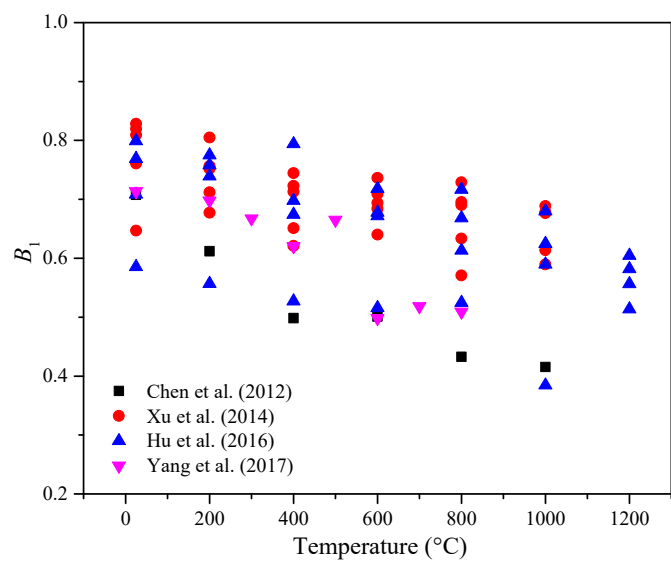

(a)

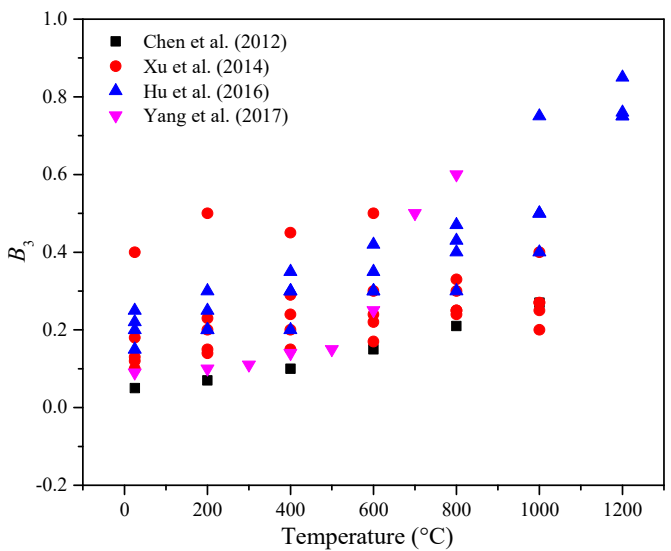

(c)

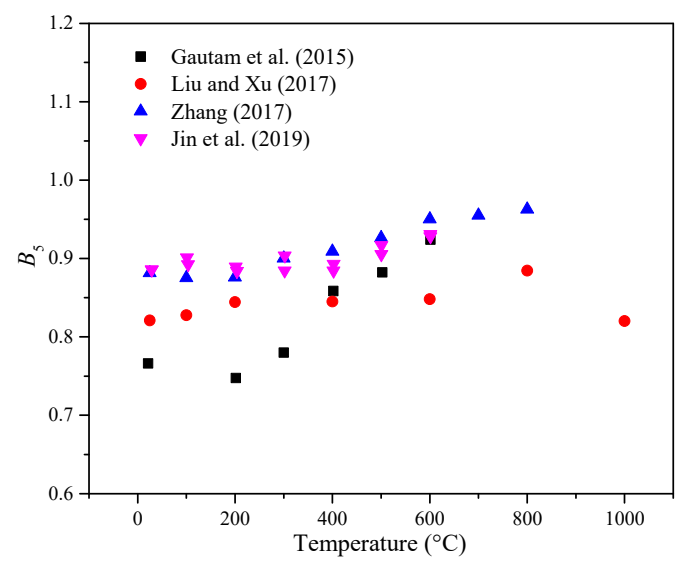

(e)

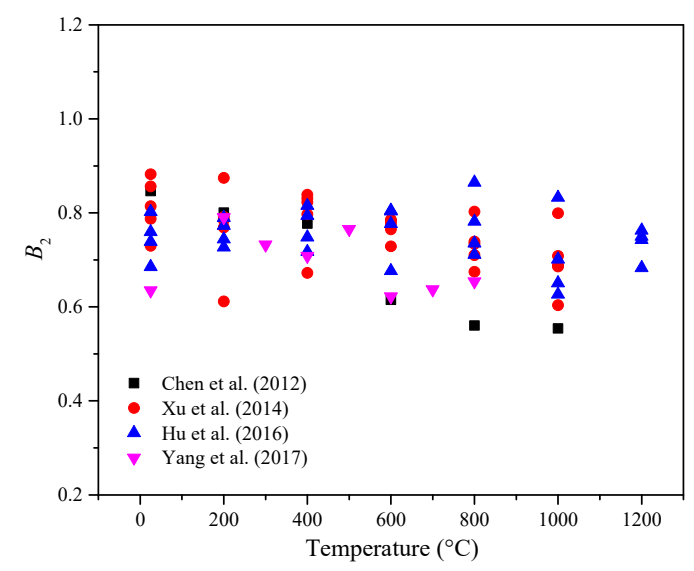

(b)

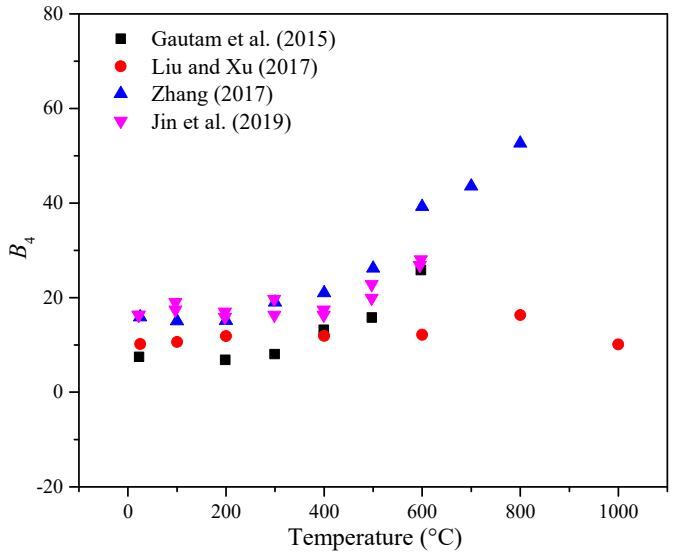

(d)

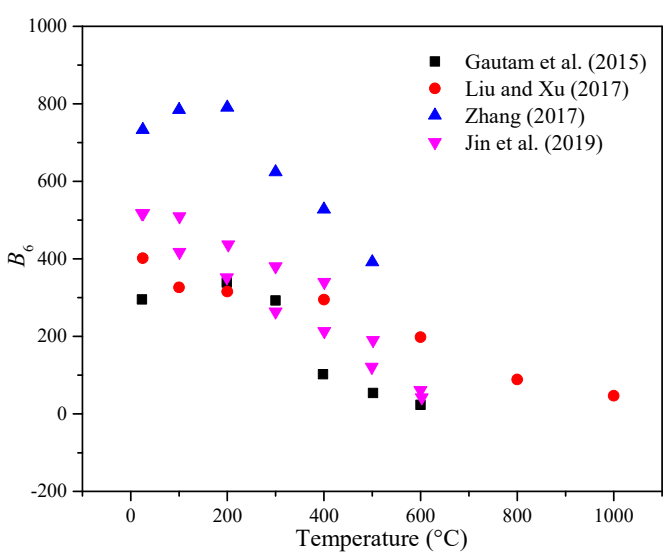

(f)

Fig. 2 Brittleness of granite treated using different temperatures: (a) $B_{1}$; (b) $B_{2}$; (c) $B_{3}$; (d) $B_{4}$; (e) $B_{5}$; and (f) $B_{6}$

effects on the brittle-plastic behavior of granite. Figure 5 shows that the granite brittleness increases gradually in the confining pressure range of 0-15 $\mathrm{MPa}$, while from $20-40 \mathrm{MPa}$, the brittleness shows significant increases. Due to the compactness and hardness of natural granite, micro-cracks will occur in its interior under natural stresses or human factors (e.g. drilling and mining). In the figure, the brittleness of granite increases gradually with the compaction of the micro-cracks under very small confining pressures. When the confining pressure exceeds the value the sample can bear, the granite pore structure further changes, resulting in new cracks and an ultimate reduction of its brittleness.

As shown in Figure 6, the brittleness of granite decreases with the confining pressure when the applied temperature exceeds $800{ }^{\circ} \mathrm{C}$. This shows that the integrity of granite itself is significantly compromised and its brittleness is nearly lost after the applied temperature exceeds $800{ }^{\circ} \mathrm{C}$, which is similar to previous studies (Brian and Fang, 1992; Zhou and He, 2002; Zhou et al., 2002; Zhou et al., 2014; Chen et al., 2018). These studies noted that the temperature is the primary factor that affects the brittle-plastic 
(a)

(b)
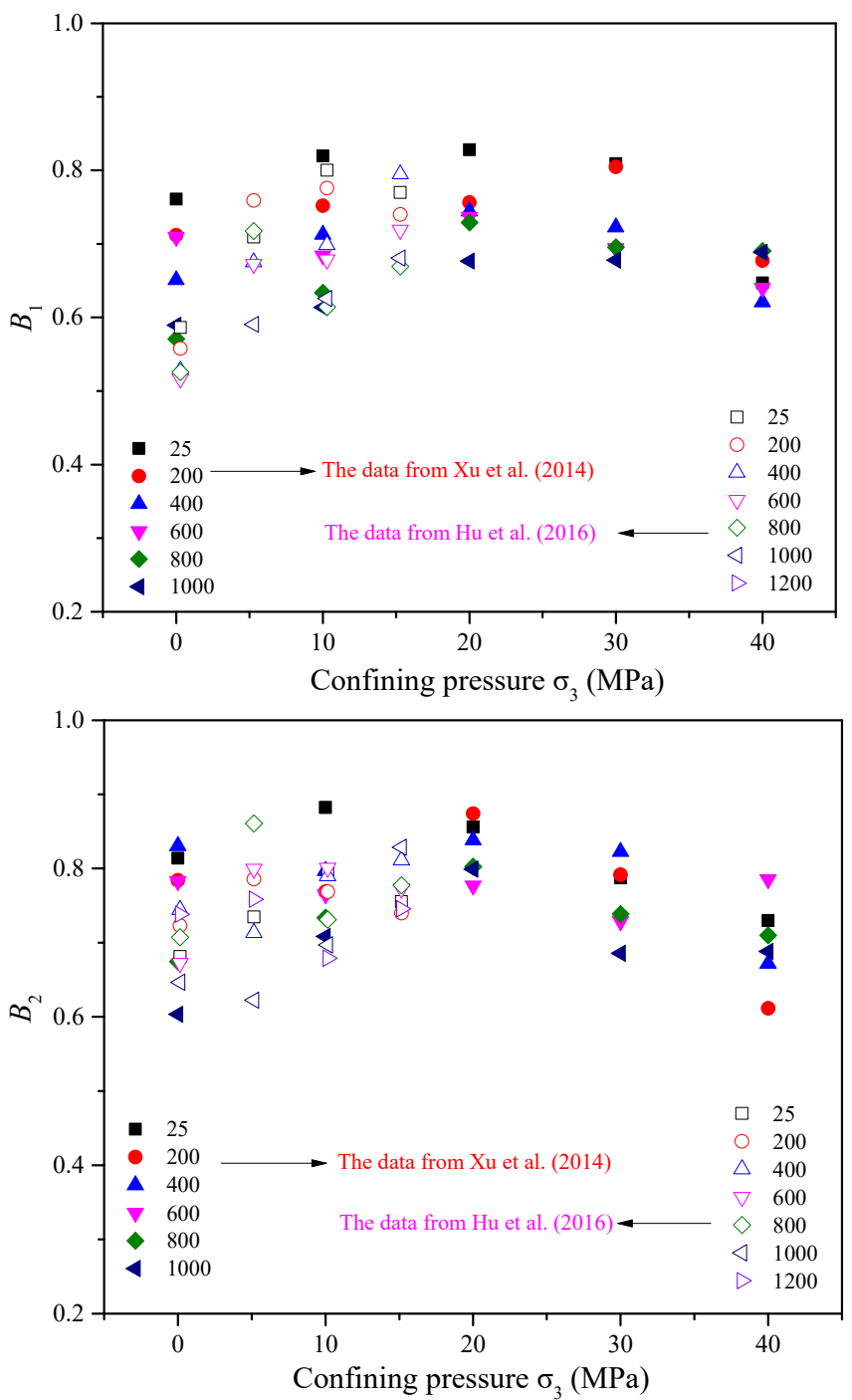

(c)

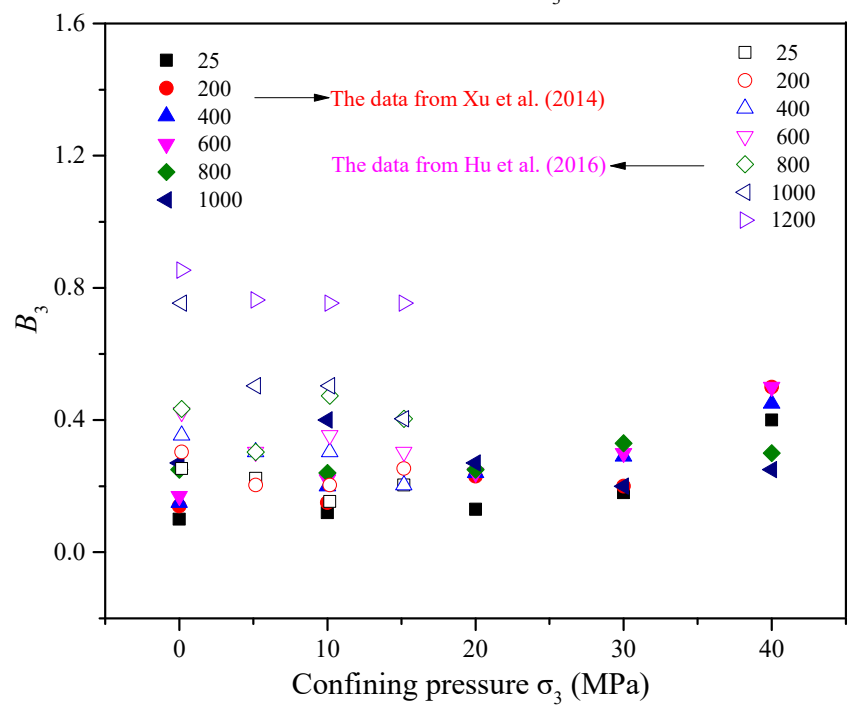

Fig. 3 Relationship between brittle plasticity of granite and the confining pressure: (a) $B_{1}$; (b) $B_{2}$; and (c) $B_{3}$.

transformation of granite in the experimental temperature-pressure range. When the temperature exceeds $800{ }^{\circ} \mathrm{C}$, granite failures are primarily from plastic deformations, which is independent of the confining pressure.

In summary, the temperature and confining pressure have important effects on granite brittleness.
Temperature and confining pressures affect the brittle plasticity of granite by changing its internal structure, including the water content, pore structure, and mineral structure. In addition, a method to quantitatively calculate the brittleness and plasticity of granite under the effects of temperature and the relationship between the confining pressure with the 


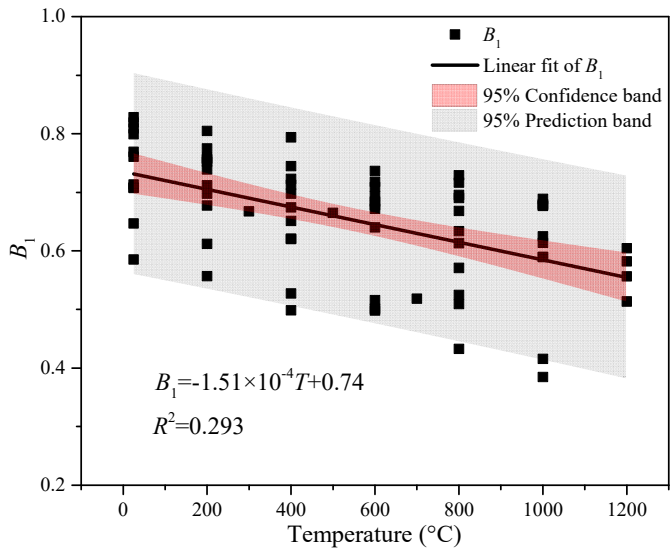

(a)

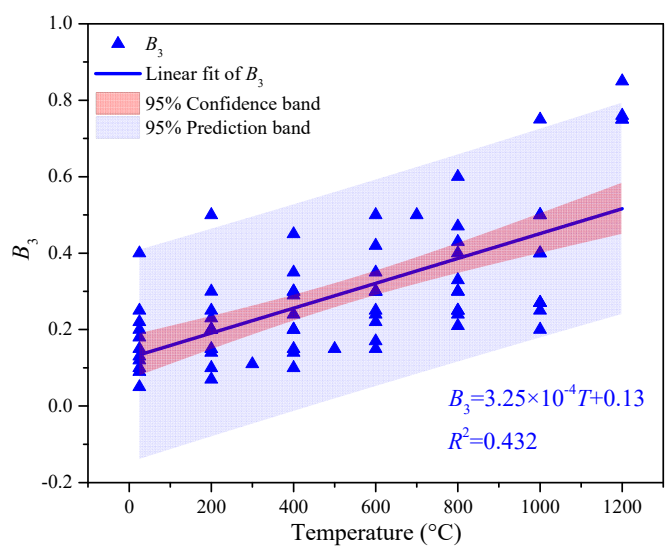

(c)

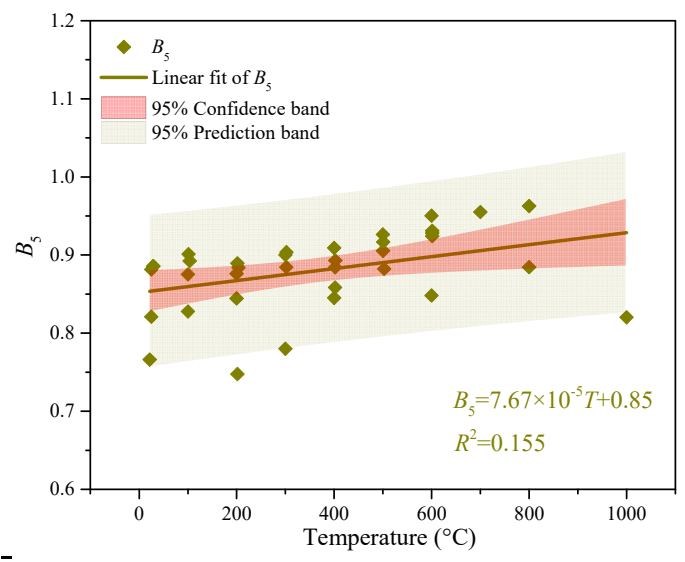

(e)

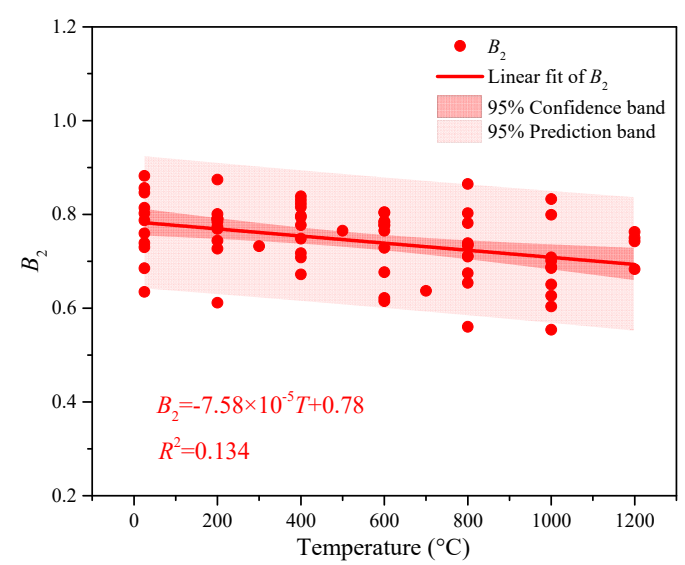

(b)

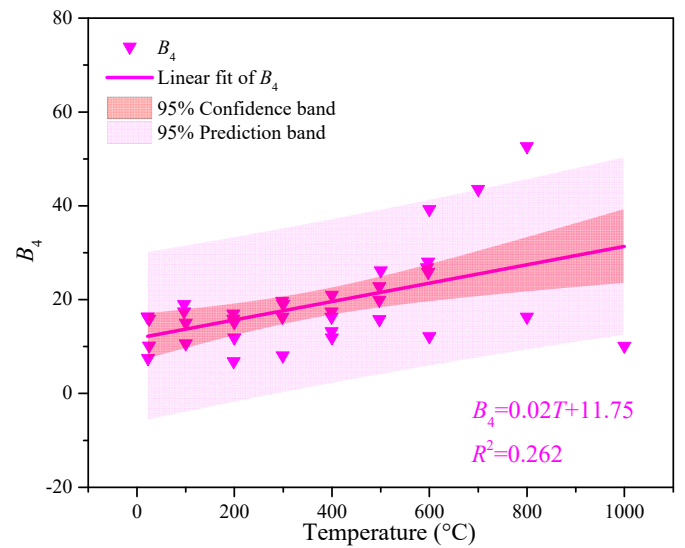

(d)

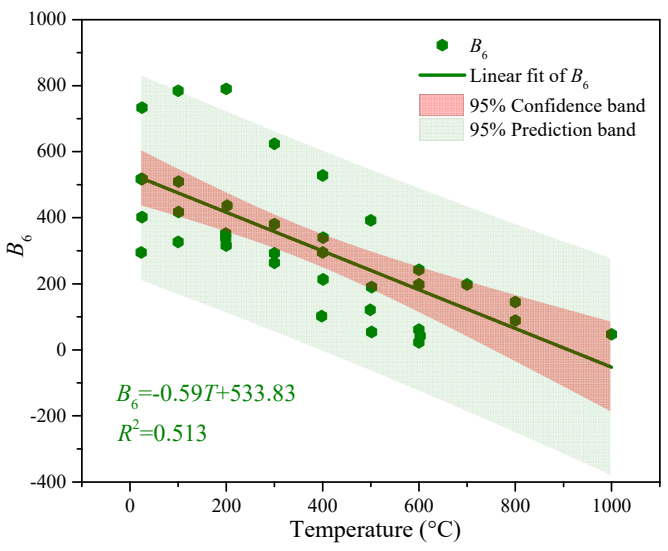

(f)

Fig. 4 Brittleness of granite treated under high temperatures: (a) $B_{1}$; (b) $B_{2}$; (c) $B_{3}$; (d) $B_{4}$; (e) $B_{5}$; and (f) $B_{6}$ (Data are from Chen et al. (2012), Xu et al. (2014), Gautam et al. (2015), Hu et al. (2016), Yang et al. (2017), Liu and Xu (2014), Zhang (2017) and Jin et al. (2019)).

brittleness and plasticity are also obtained in this study. The results are of great significance for engineering construction and geological research.

\section{CONCLUSION}

In this paper, theoretical methods to quantitatively calculate the brittle-plastic properties of rock and the data of rock mechanics under varying temperatures and confining pressures are summarized.
Combining experimental results with the theoretical calculation method of brittleness and plasticity, a quantitative calculation and evaluation method for the brittleness and plasticity of granite under the effects of temperature and confining pressure is proposed. The main conclusions are as follows.

1. High temperatures cause thermal damage to the internal structure of granite, which leads to the transformation from brittle failure to plastic 
(a)

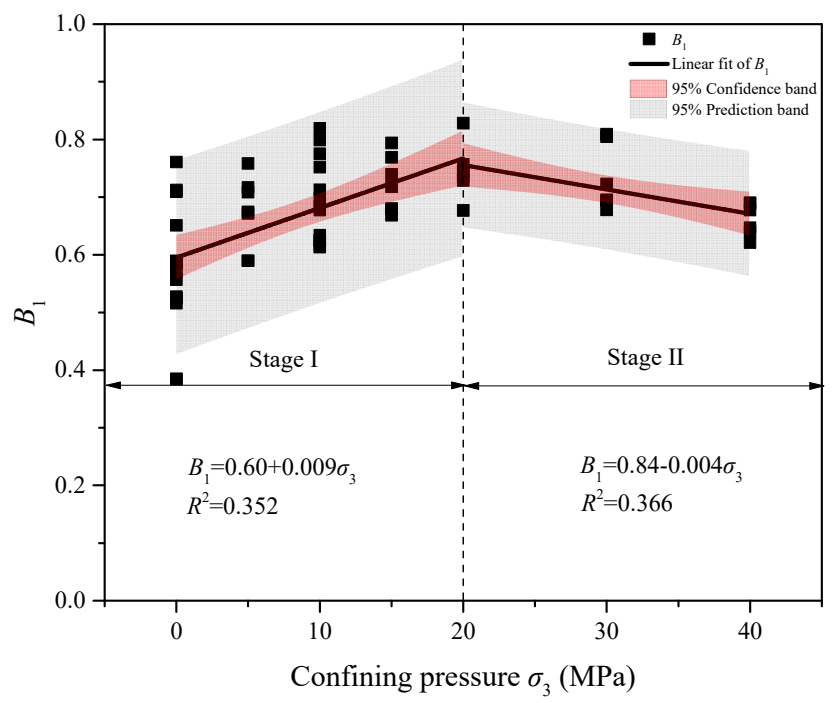

(b)

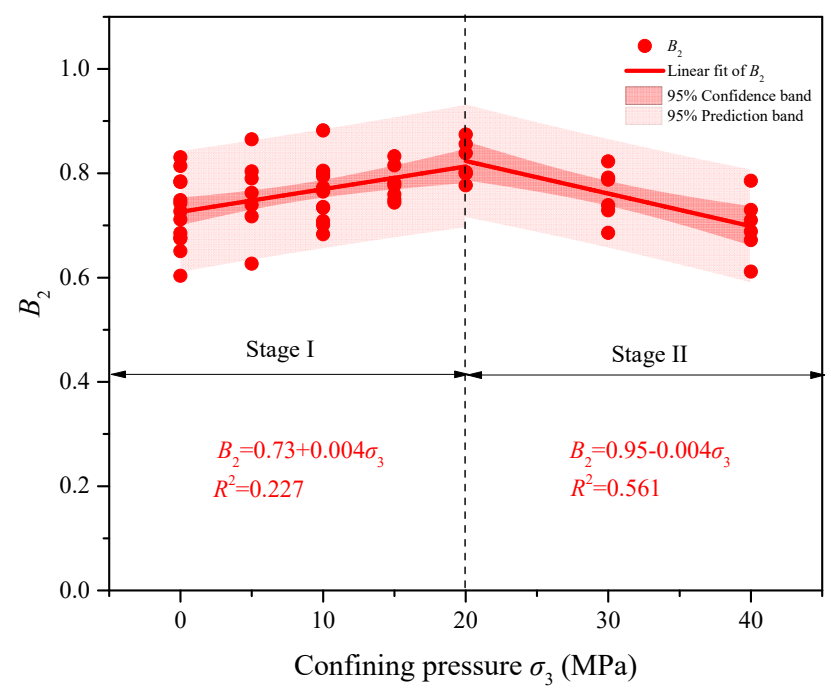

(c)

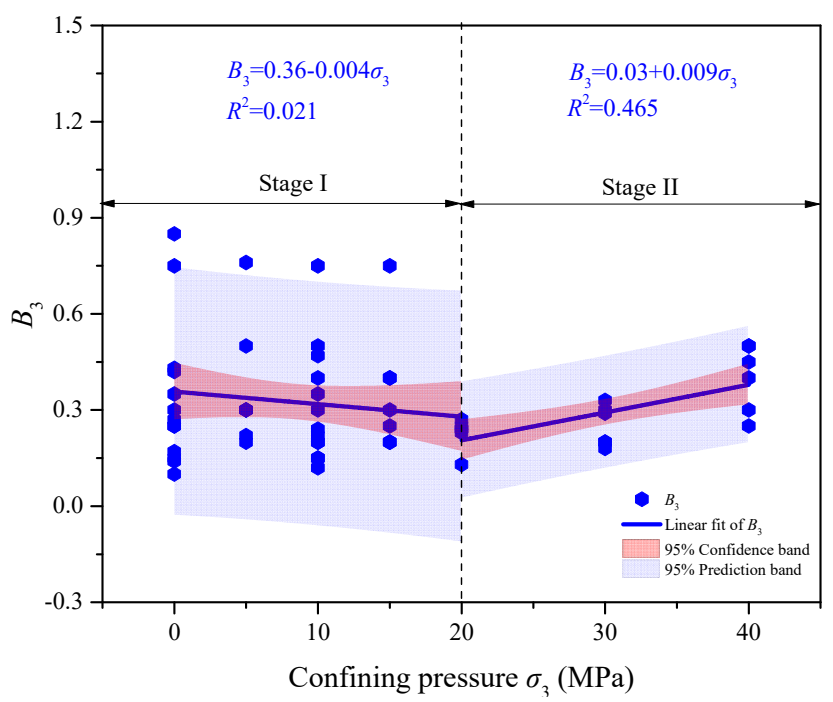

Fig. 5 Relationship between the brittle plasticity of granite and confining pressure ((a) $B_{1}$; (b) $B_{2}$; and (c) $\left.B_{3}\right)$ (Data are from Xu et al. (2014) and Hu et al. (2016)).

failure. Based on previous studies, six empirical equations to quantitatively calculate the relationship between the brittleness and temperature of granite are obtained. Comparing the six empirical equations shows that B3 and B6 can more accurately and quantitatively express the relationship between the brittleness and temperature of granite.

2. When the applied experimental confining pressure is lower than $20 \mathrm{MPa}$, the internal pore structure and fractures of granite are recompacted and reduced, which gradually 

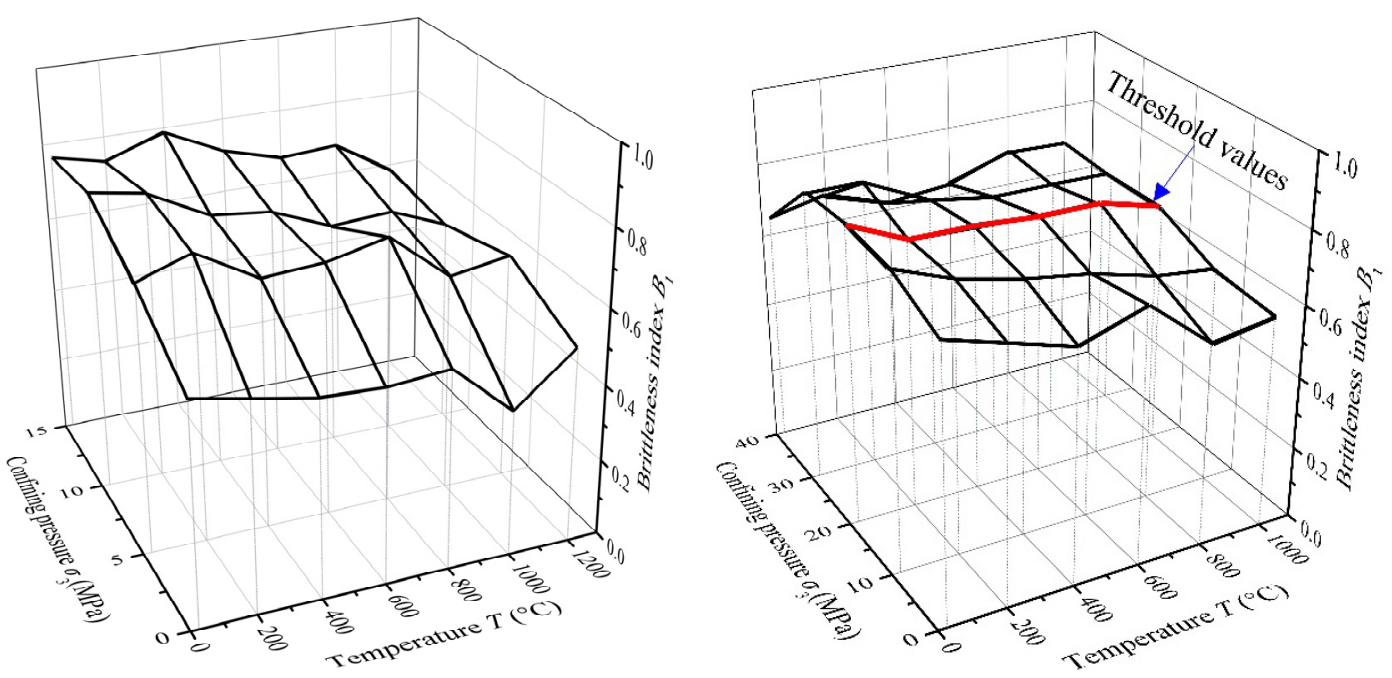

(a)
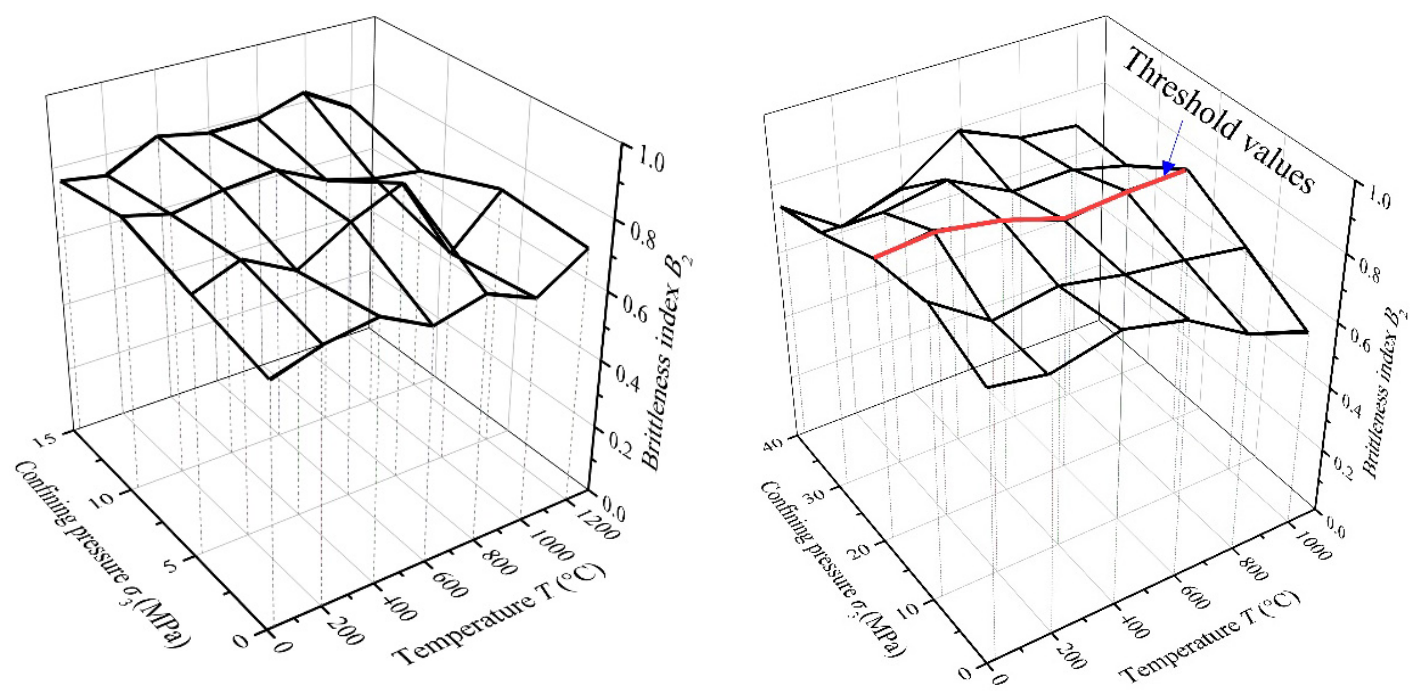

(c)
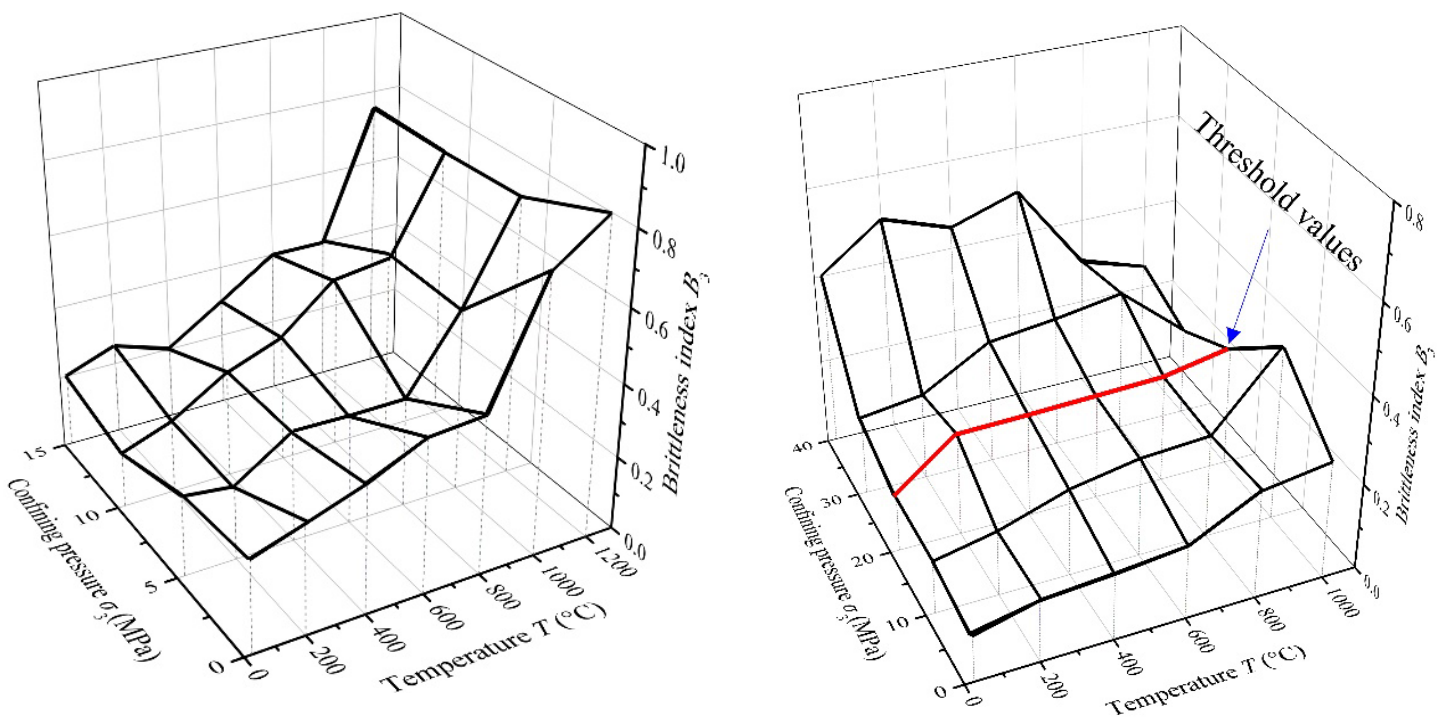

(e)

Fig. 6 The relationship between the brittleness with the temperature and confining pressure ((a) and (b) $B_{1}$; (c) and (d) $B_{2}$; (e) and (f) $B_{2}$ ) (Data from Xu et al. (2014) and Hu et al. (2016)). 
enhances its brittleness. As the confining pressure further increases, the pore structure of granite will change again after exceeding 20 $\mathrm{MPa}$. This causes new cracks to appear, which ultimately leads to a decrease in the granite brittleness.

3. $800{ }^{\circ} \mathrm{C}$ is the abrupt temperature for the brittleplastic transformation of granite. In addition, the results also show that when temperature is higher than $800{ }^{\circ} \mathrm{C}$, the brittle-plastic transformation of granite is primarily affected by temperature and not the confining pressure.

\section{EXPECTATION}

Variations in $B_{1}, B_{2}$, and $B_{3}$ show that different confining pressures have different effects on the brittle plasticity of granite, which is of particular interest. Figure 5 shows that the brittleness of granite increases at confining pressures from 0-15 $\mathrm{MPa}$ and decreases at confining pressures from 20-40 $\mathrm{MPa}$. Therefore, it is inferred that the brittleness of granite is related to the original confining pressure of granite samples. That is, the original confining pressures of granite samples in the two experiments ( $\mathrm{Hu}$ et al., 2016; Xu et al., 2014) are approximately 15 and 20 $\mathrm{MPa}$, respectively, at a certain underground depth. After granite is exposed to the earth's surface due to tectonic actions, weathering, or human factors (e.g. drilling and mining) from a certain depth underground, the confining pressure is released, causing the internal pore structure to change and cracks to expand. In the studies of $\mathrm{Hu}$ et al. (2016) and $\mathrm{Xu}$ et al. (2014), the brittleness of granite increases gradually due to the reintroduction of the confining pressure, which recompacts and reduces the internal pore structure and fractures of granite. When the confining pressure exceeds the original value of the sample, the pore structure of the granite changes and results in new cracks, which ultimately lead to a decreased brittleness.

However, this is only a conjecture, because the two considered references did not specify the depth of the granite samples or other detailed information to prove this conjecture. If the conjecture is correct, it is of great significance for changes in geological conditions for granite-containing regions adopted by research institutes to study the relationship between confining pressures and rock brittleness-plasticity under laboratory conditions. It is hoped that more such experiments will be conducted in the future to verify this conjecture.

\section{ACKNOWLEDGEMENTS}

This research was supported by the National Natural Science Foundation of China (Grant No. 41672279 and 41807233), the Natural Science Foundation of Jiangsu Province (Grant No. BK20180662). We also want to thank the technicians who helped us during the experiment and the anonymous reviewer for the constructive comments.

\section{REFERENCES}

Ai, C., Zhang, J., Li, Y.W. et al.: 2016, Estimation criteria for rock brittleness based on energy analysis during the rupturing process. Rock Mech. Rock Eng., 49, 12, 4681-4698. DOI: 10.1007/s00603-016-1078-x

Altindag, R.: 2002, The evaluation of rock brittleness concept on rotary blast hole drills. J. S. Afr. I. Min. Metall., 102, 1, 61-66.

Amitrano, D.: 2003, Brittle-ductile transition and associated seismicity: Experimental and numerical studies and relationship with the $\mathrm{b}$ value. J. Geophys. Res. Solid Earth, 108, B1, 1-8. DOI: 10.1029/2001JB000680

Andreev, G.E.: 1995, Brittle Failure of Rock Materials. CRC Press, Florida.

Brian, E. and Fang, H.: 1992, Brittle-ductile transition of rocks-the latest experimental and theoretical progress. Progress in Geophysics, 7, 1, 75-89, (in Chinese).

Byerlee, J.D.: 1968, Brittle-ductile transition in rocks. J. Geophys. Res., 73, 14, 4741-4750. DOI: $10.1029 / \mathrm{jb} 073 \mathrm{i} 014 \mathrm{p} 04741$

Chen, G., Zhao, C., Wei, T. et al.: 2018, Rock brittleness evaluation method based on full stress-strain curve and initiation stress. Chin. J. Rock Mech. Eng., 37, 1, 51-59, (in Chinese). DOI: 10.13722/j.cnki.jrme.2017.0499

Chen, G., Jiang, W., Sun, X. et al.: 2019, Quantitative evaluation of rock brittleness based on crack initiation stress and complete stress-strain curves. Bull. Eng. Geol. Environ., 78, 5919-5936. DOI: $10.1007 / \mathrm{s} 10064-019-01486-2$

Chen, Y.L., Ni, J., Shao, W. and Azzam, R.; 2012, Experimental study on the influence of temperature on the mechanical properties of granite under uniaxial compression and fatigue loading. Int. J. Rock Mech. Min. Sci., 56, 62-66.

DOI: 10.1016/j.ijrmms.2012.07.026

Duan, Z.F. and Wang, X.Y.: 2012, Study on optimal reinjection strategy of geothermal field: a case study from Tianjin, North China. Adv. Mater. Res., 7, 524527.

DOI: 10.4028/www.scientific.net/AMR.524-527.3165

Duda, M. and Renner, J.: 2013, The weakening effect of water on the brittle failure strength of sandstone. Geophys. J. Int., 192, 3, 1091-1108.

DOI: $10.1093 / \mathrm{gji} / \mathrm{ggs} 090$

Ellis, S. and Stöckhert, B.: 2004, Elevated stresses and creep rates beneath the brittle-ductile transition caused by seismic faulting in the upper crust. J. Geophys. Res., 109(B5), B05407. DOI: $10.1029 / 2003$ jb002744

Emirov, S.N. and Ramazanova, A.E.: 2013, Experimental study of heat transfer on the borders of grains in ordered and disordered media. Bull. Russ. Acad. Sci. Phys., 77, 3, 284-287. DOI: $10.3103 / \mathrm{S} 1062873813030106$

Evans, B., Fredrich, J.T. and Wong, T.F.: 1990, The brittleductile transition in rocks: Recent experimental and theoretical progress. American Geophysical Union, The Brittle-Ductile Transition in Rocks, Geophysical Monograph, 56. DOI: 10.1029/GM056p0001

Freire, D.M., Fort, R. and Varas, M.J.: 2016, Thermal stress-induced microcracking in building granite. Eng. Geol., 206, 83-93. DOI: 10.1016/j.enggeo.2016.03.005

Gautam, P.K., Verma, A.K., Maheshwar, S. et al.: 2015, Thermomechanical analysis of different types of sandstone at elevated temperature. Rock Mech. Rock 
Eng., 49, 5, 1985-1993.

DOI: $10.1007 / \mathrm{s} 00603-015-0797-8$

Ghassemi, A., Tarasovs, S. and Cheng, A.H.D.: 2007, A 3-D study of the effects of thermomechanical loads on fracture slip in enhanced geothermal reservoirs. Int. J. Rock Mech. Min. Sci., 44, 8, 1132-1148. DOI: $10.1016 /$ j.ijrmms.2007. 07.016

Girggs, D.T. and Handin, J.: 1960, Observations on fracture and a hypothesis of earthquakes. In: Griggs, D. T. and Handin, J. (eds.), Rock Deformation. Geol. Am. Memoir, 79, 347-364.

Gong, Q.M. and Zhao, J.: 2007, Influence of rock brittleness on TBM penetration rate in Singapore granite. Tunn. Undergr. Sp. Tech., 22, 3, 317-324. DOI: 10.1016/j.tust.2006.07.004

Gunaydin, O., Kahraman, S. and Fener, M.: 2004, Sawability prediction of carbonate rocks from brittleness indexes. J. S. Afr. I. Min. Metall., 104, 4, 239-244.

Heard, H.C.: 1960, Transition from brittle fracture to ductile flow in Solenhofen limestone as a function of temperature, confining pressure and interstitial fluid pressure, In: Griggs, D. T. and Handin, J. (eds.), Rock Deformation. Geol. Am. Memoir, 79, 193-226.

Horii, H. and Nematnasser, S.: 1986, Brittle failure in compression: splitting, faulting and brittle-ductile transition. Philos. Trans. R. Soc. Lond., 319, 1549, 337-374. DOI: 10.1098/rsta.1986.0101

Hu, S., Zhang, G., Zhang, M., Jiang, X. and Chen, Y.: 2016, Deformation characteristic test and damage mechanics analysis of beishan granite after heat treatment. Rock Soil. Mech., 12, 3428-3454, (in Chinese).

DOI: $10.16285 /$ j.rsm.2016.12.011

Hucka, V. and Das, B.: 1974, Brittleness determination of rocks by different methods. Int. J. Rock Mech. Min. Sci. Geomech. Abstr., 11, 10, 389-392. DOI: 10.1016/0148-9062(74)91109-7

Hudson, J.A., Stephansson, O., Jing, L. et al.: 2001, Coupled T-H-M issues relating to radioactive waste repository design and performance. Int. J. Rock Mech. Min. Sci., 38, 1, 143-161. DOI: $10.1016 /$ S1365-1609(00)00070-8.

Jarvie, D.M., Hill, R.J., Ruble, T.E. and Pollastro, R.M.: 2007, Unconventional shale-gassystems: the Mississippian Barnett Shale of north-central Texas as one model for thermogenic shale-gas assessment. AAPG Bull., 91, 4, 475-499.

DOI: $10.1306 / 12190606068$

Jin, P., Hu, Y., Shao, J. et al.: 2019, Influence of different thermal cycling treatments on the physical, mechanical and transport properties of granite. Geothermics, 78, 118-128.

DOI: 10.1016/j.geothermics.2018.12.008

Jin, X., Shah, S.N, Roegiers, J.C. and Zhang, B.: 2014a, Fracability evaluation in shale reservoirs-an integrated petrophysics and geomechanics approach. In: Proceedings of the SPE Hydraulic Fracturing Technology Conference, Society of Petroleum Engineers.

Jin, X., Shah, S.N., Truax, J.A. and Roegiers, J.C.: 2014b, A practical petrophysical approach for brittleness prediction from porosity and sonic logging in shale reservoirs. In: SPE Annual Technical Conference and Exhibition, Society of Petroleum Engineers.

Kahraman, S. and Altindag, R.: 2004, A brittleness index to estimate fracture toughness. Int. J. Rock Mech. Min.
Sci., 41, 2, 343-348.

DOI: $10.1016 /$ j.ijrmms.2003.07.010

Kaxiras, E. and Duesbery, M.S.: 1993, Free energies of generalized stacking faults in Si and implications for the brittle-ductile transition. Phys. Rev. Lett., 70, 24, 3752-3755. DOI: 10.1103/PhysRevLett.70.3752

Liu, S. and Xu, J.: 2014, Mechanical properties of Qinling biotite granite after high temperature treatment. Int. J. Rock Mech. Min. Sci., 71, 188-193. DOI: $10.1016 /$ j.ijrmms.2014.07.008

Liu, S. and Xu, J.: 2015, An experimental study on the physico-mechanical properties of two post-hightemperature rocks. Eng. Geol., 185, 4, 63-70. DOI: $10.1016 /$ j.enggeo.2014.11.013

Luan, X., Di, B., Wei, J., Li, X., Qian, K., Xie, J. and Ding, P.: 2014, Laboratory measurements of brittleness anisotropy in synthetic shale with different cementation. In: Proceedings of the 2014 SEG Annual Meeting. Denver, Society of Exploration Geophysicists, 3005-3009.

Meng, F., Zhou, H., Zhang, C. et al.: 2015, Evaluation methodology of brittleness of rock based on postpeak stress-strain curves. Rock Mech. Rock Eng., 48, 5, 1787-1805. DOI: 10.1007/s00603-014-0694-6

Niemeijer, A.R. and Spiers, C.J.: 2005, Influence of phyllosilicates on fault strength in the brittle-ductile transition: insights from rock analogue experiments. Geological Society London, Special Publications, $245,1,303-327$

DOI: 10.1144/GSL.SP.2005.245.01.15

Nolter, M.A. and Vice, D.H.: 2004, Looking back at the Centralia coal fire: a synopsis of its present status. Int. J. Coal Geol., 59, 1-2, 99-106. DOI: 10.1016/j.coal.2003.12.008

Ozguven, A. and Ozcelik, Y.: 2013, Investigation of some property changes of natural building stones exposed to fire and high heat. Constr. Build. Mater., 38, 813821. DOI: 10.1016/j.conbuildmat.2012.09.072

Paterson, M.S.: 2013, Brittle-Ductile Transition. Encyclopedia of Tribology, 273-279. DOI: $10.1007 / 978-3-662-11720-08$

Pearson, C.F., Fehler, M.C. and Albright, JN.: 1983, Changes in compressional and shear-wave velocities and dynamic moduli during operation of a hot dry rock geothermal system. J. Geophys. Res., Solid Earth, 88, B4, 3468-3475. DOI: $10.1029 / J B 088$ iB04p03468

Rutqvist, J., Tsang, C., Tsang, Y. et al.: 2005, Coupled thermal hydrological mechanical analyses of the Yucca Mountain Drift Scale Test Comparison of field measurements to predictions of four different numerical models. Int. J. Rock Mech. Min. Sci., 42, 5, 680-697. DOI: 10.1016/j.ijrmms.2005.03.008

Simpson, C.: 1985, Deformation of granitic rocks across the brittle-ductile transition. J. Struct. Geol., 7, 5, 503-511. DOI: 10.1007/s00603-016-0922-3

Smith, A.G. and Pells, P.J.N.: 2008, Impact of fire on tunnels in Hawkesbury sandstone. Tunn. Undergr. Sp. Tech., 23, 1, 65-74. DOI: 10.1016/j.tust.2006.11.003

Somerton, W.H. and Boozer, G.D.: 1961, A method of measuring thermal diffusivities of rocks at elevated temperatures. AIChE J., 7, 1, 87-90. DOI: 10.1002/aic.690070121

Stacey, T.R.: 2016, Addressing the consequences of dynamic rock failure in underground excavations. Rock Mech. Rock Eng., 49, 10, 4091-4101. DOI: 10.1007/s00603-016-0922-3 
Sun, S.Z., Wang, K.N., Yang, P., Li, X.G., Sun, J.X., Liu, B.H. and Jin, K.: 2013, Integrated prediction of shale oil reservoir using Pre-Stack Algorithms for brittleness and fracture detection. Beijing, International Petroleum Technology Conference.

Sun, Q., Zhang, Z., Xue, L. and Zhu, S.: 2013, High temperature phase transformation and changes in physical and mechanical properties of rocks. Chin. J. Rock Mech. Eng. 32, 5, 935-942, (in Chinese). DOI: $10.3969 /$ j.issn.1000-6915.2013.05.011

Sun, Q., Zhang, W., Xue, L., Zhang, Z. and Su, T.: 2015, Thermal damage pattern and thresholds of granite. Environ. Earth Sci., 74, 3, 2341-2349. DOI: $10.1007 / \mathrm{s} 12665-015-4234-9$

Tang, X., Wang, M., Dong, C., Tong, J. and Wang, Y.: 2016, Sensitivity analysis for shear strength of flat interface between shotcrete and granite in high temperature tunnel. J. Adv. Mater. Res., 112, 155160.

Tarasov, B. and Potvin, Y.: 2013, Universal criteria for rock brittleness estimation under triaxial compression. Int. J. Rock Mech. Min. Sci., 59, 57-69. DOI: $10.1016 /$ j.ijrmms.2012.12.011

Ünal, S.: 1995, A review of spontaneous combustion of coals. Liq. Fuels Technol. 13, 9, 1103-1120. DOI: $10.1080 / 08843759508947726$

Voigt, S., Tetzlaff, A., Zhang, J. et al.: 2004, Integrating satellite remote sensing techniques for detection and analysis of uncontrolled coal seam fires in North China. Int. J. Coal Geol., 59, 1-2, 121-136. DOI: $10.1016 /$ j.coal.2003.12.013

Walsh, J.B. and Brace, W.F.: 1964, A fracture criterion for brittle anisotropic rock. J. Geophys. Res., 69, 16, 3449-3456. DOI: 10.1029/jz069i016p03449

Wan, Z., Zhao, Y., Dong, F. et al.: 2007, Experimental study on mechanical properties of granite under high temperature and triaxial stress. Chin. J. Rock Mech. Eng., 27, 1, 72-77, (in Chinese).

DOI: 10.3321/j.issn:1000-6915.2008.01.011

Wang, S., Liu, J., Sun, Y., Liu, S., Gao, X., Sun, C. and Li, H.: 2018, Study on the geothermal production and reinjection mode in Xiong County. J. Groundw. Sci. Eng., 5, 3, 178-186.

DOI: $10.19637 /$ j.cnki.2305-7068.2018.03.003

Wang, L.L., Bornert, M., Yang, D.S. et al.: 2015, Microstructural insight into the nonlinear swelling of argillaceous rocks. Eng. Geol., 193, 435-444. DOI: 10.1016/ j.enggeo.2015.05.019.

Wang, F.P. and Gale, J.F.: 2009, Screening criteria for shale-gas systems. Gulf Coast Association of Geological Transactions, 59, 779-793.

Whitehouse, A.E. and Mulyana, A.A.S.: 2004, Coal fires in Indonesia. Int. J. Coal Geol., 59, 1-2, 91-97. DOI: $10.1016 /$ j.coal.2003.08.010

Wong, T.F. and Baud, P.: 2012, The brittle-ductile transition in porous rock: A review. J. Struct. Geol., 44, 25-53.

DOI: 10.19637/j.cnki.2305-7068.2018.03.003

Xi, B. and Zhao., Y.: 2010, Experimental study on the thermophysical and mechanical properties of borehole surrounding rock in granite under high temperature and pressure. Chin. J. Rock Mech. Eng., 29, 6, 1246-1253, (in Chinese).

Xu, X., Gao, F. and Shen, X.: 2010, Study on mechanical properties and micropore structure characteristics of granite after high temperature. Geotech. Mech., 31, 6, 1752-1758, (in Chinese).

DOI: $10.3969 /$ j.issn.1000-7598.2010.06.012
Xu, X., Gao, F. and Zhang, Z.: 2014, Triaxial compression test of granite after high temperature action. Geotech. Mech., 35, 11, 3177-3183, (in Chinese).

Xu, X., Gao, F., Zhang, Z.Z. et al.: 2015, Experimental study of the effect of loading rates on mechanical properties of granite at real-time high temperature. Rock Soil Mech., 36, 8, 2184-2192, (in Chinese). DOI: $10.16285 /$ j.rsm.2015.08.008

Yang, S.Q., Yang, D.S., Jing, H.W., Li, Y.H. and Wang, S.Y.: 2012, An experimental study of the fracture coalescence behaviour of brittle sandstone specimens containing three fissures. Rock Mech. Rock Eng., 45, 4, 563-582. DOI: 10.1007/s00603-011-0206-x

Yang, S,Q., Ranjith, P.G., Jing, H.W. et al.: 2017, An experimental investigation on thermal damage and failure mechanical behavior of granite after exposure to different high temperature treatments. Geothermics, 65, 180-197. DOI: $10.1016 /$ j.geothermics.2016.09.008

Yarali, O. and Kahraman, S.: 2011, The drillability assessment of rocks using the different brittleness values. Tunn. Undergr. Sp. Tech., 26, 2, 406-414. DOI: $10.1016 /$ j.tust.2010.11.013

Yoshitaka, N., Naoki, H., Tetsuro, Y. and Katsuhiko, K.: 2010, Effects of relative humidity and temperature on subcritical crack growth in igneous rock. Int. J. Rock Mech. Min. Sci., 47, 4, 640-646. DOI: $10.1016 /$ j.ijrmms.2010.04.009

Zhang. D., Ranjith, P.G. and Perera, M.S.A.: 2016, The brittleness indices used in rock mechanics and their application in shale hydraulic fracturing: A review. J. Petrol. Sci. Eng., 143, 158-170. DOI: $10.1016 /$ j.petrol.2016.02.011

Zhang, W.Q.: 2017, Study on microscopic mechanism of rock thermal damage and evolution characteristics of macro physical and mechanical properties. Xuzhou, China University of Mining and Technology, (in Chinese).

Zhang, W., Sun, Q., Hao, S. and Geng, J.: 2016, Experimental study on the variation of physical and mechanical properties of rock after high temperature treatment. Appl. Therm. Eng., 98, 1297-1304. DOI: 10.1016/j.applthermaleng.2016.01.010

Zhou, Y., Jiang, H. and He, C.: 2002, Experimental study on brittle-plastic transformation and instability patterns of Juyongguan granite under different temperatures and pressures. China Earthquake, 18, 4, 389-400, (in Chinese). DOI: $10.3969 /$ j.issn. 1001-4683.2002.04.010

Zhou, Yo. and He, C.: 2002, The transformation of crustal rock deformation behavior and its temperaturepressure conditions. Seismology, 2, 167-178, (in Chinese). DOI: $10.3969 /$ j.issn.0253-4967.2000.02.010

Zhou. C., Wan, Z., Zhang, Y. et al.: 2018, Experimental study on hydraulic fracturing of granite under thermal shock. Geothermics, 71, 146-155. DOI: 10.1016/j.geothermics.2017.09.006

Zhou, H., Meng, F., Zhang, C. et al.: 2014, Quantitative evaluation method of rock brittleness based on stressstrain curve. Chin. J. Rock Mech. Eng., 33, 6, 1114 1122, (in Chinese).

DOI: 10.3969/j.issn.1000-6915.2014.06.003 